\title{
Sodium Taurocholate Modifies the Bile Acid-Independent Fraction of Canalicular Bile Flow in the Rhesus Monkey
}

\author{
Alfred L. Baker, R. A. B. Wood, A. R. Moossa, and James L. Boyer, Liver Study \\ Unit, Department of Medicine and Department of Surgery, University of \\ Chicago School of Medicine, Chicago, Illinois 60637
}

A B S T RACT Bile acid-independent secretion and the choleretic response to taurocholate were determined in rhesus monkeys fitted with indwelling silastic cannulas in the common bile ducts. Bile acids were infused intravenously in random order at $3.5,7.0$, or $10.5 \mu \mathrm{mol} / \mathrm{min}$ for $1.5 \mathrm{~h}$ each. When data were analyzed with a single regression line, bile flow increased in proportion to the level of bile acid secretion, although the $y$-intercepts (the conventional measurement of bile acid-independent secretion) varied widely $(77.9 \pm 40.9$ $\mathrm{ml} / 24 \mathrm{~h}$ ). The variation in $y$-intercepts was observed between animals and with repeated studies in the same animal and could not be explained by sex differences or the effects of the indwelling silastic cannulas, but seemed to be related to the order of bile acid infusion. With only two taurocholic acid infusion rates (7.0 and $3.5 \mu \mathrm{mol} / \mathrm{min}$ ), $\left[{ }^{14} \mathrm{C}\right]$ erythritol clearance was greater per mole of secreted bile acid when the initial bile acid infusion was at the high level, but approached zero at low bile acid secretion rates, which suggests that socalled bile acid-independent canalicular flow is closely related to bile acid secretion or is small in size. The augmentation in $\left[{ }^{14} \mathrm{C}\right]$ erythritol clearance when the high infusion rate was given first was also associated with an increase in biliary clearance of $\left[{ }^{3} \mathrm{H}\right]$ inulin, which indicates that the premeability to inulin was also enhanced. Identical experiments which substituted equimolar infusions of a nonmicelle-forming bile acid (taurodehydrocholate) for taurocholate failed to demonstrate any difference in choleretic response or biliary clearance of $\left[{ }^{3} \mathrm{H}\right]$ inulin with the order of bile acid infusion. These experiments demonstrate that a micelleforming bile acid, taurocholate, can increase the perme-

This work was presented in part at the meeting of the American Association for the Study of Liver Disease in Chicago, Ill., 5-6 November 1976 and appeared in abstract form in 1976. Gastroenterology. 71: 895.

Dr. Boyer is a recipient of Academic Career Development Award AM-70218 from the U. S. Public Health Service.

Received for publication 10 February 1978 and in revised form 29 January 1979. ability of the biliary system to large molecular weight solutes and simultaneously modify the $y$-intercept and the volume of bile secreted in response to the transported bile acid. Taurocholate may, therefore, modify its own choleretic response, perhaps by altering the structure or function of bile secretory membranes, and appears to be a major determinant of so-called bile acid-independent flow in rhesus monkeys.

\section{INTRODUCTION}

According to present concepts, bile secretion is initiated by the active transport of bile acids from liver cells into the lumen of the bile canaliculus. The osmotic gradient created by the concentration of bile acids in the canalicular lumen results in passive diffusion of water and electrolytes and produces bile flow. Recent investigations with inert markers of canalicular flow such as erythritol and mannitol suggest that this primary bile production in the rat $(1,2)$, rabbit (3), rhesus monkey $(4,5)$, and man $(6,7)$ may not be entirely explained by the osmotic effects of the secreted bile acids. Sodium transport and the activity of the canalicular membrane-bound enzyme $\mathrm{Na}^{+}, \mathrm{K}^{+}$-ATPase have been postulated as possible determinants of this bile acidindependent canalicular secretion $(3,8)$. This hypothesis is derived from indirect studies which have used various drugs and hormones to stimulate bile acidindependent canalicular flow in vivo and which have documented parallel changes in the activity of $\mathrm{Na}^{+}$, $\mathrm{K}^{+}$-ATPase in isolated liver plasma membranes from the same animal (9). For example, ethinyl estradiol inhibits bile acid-independent flow and $\mathrm{Na}^{+}, \mathrm{K}^{+}$-ATPase activity $(10,11)$, whereas thyroid hormone (12) and phenobarbital $(1,13)$ stimulate bile acid-independent flow and $\mathrm{Na}^{+}, \mathrm{K}^{+}$-ATPase activity. However, other mechanisms for modifying canalicular secretion may also exist, including other ion pumps or alterations in the fluidity or permeability of membranes or junctional complexes within the biliary system. The bile acids taurocholate and dehydrocholate, themselves, alter 
canalicular membrane structure during choleresis while taurocholate increases canalicular membrane phospholipid content (14) and may increase the activity of $\mathrm{Na}^{+}, \mathrm{K}^{+}$-ATPase when infused chronically into rats (15). Bile acids also increase the permeability of hepatocyte junctional complexes in the rat and may allow fluid transfer into bile via paracellular shunt pathways (16).

We have recently studied bile production in rhesus monkeys utilizing indwelling silastic catheters placed in the common duct for repeated collections of bile output (5). In these investigations a linear relationship between $\left[{ }^{14} \mathrm{C}\right]$ erythritol clearance (canalicular bile flow) and bile acid secretion rate was observed. However, bile acid-independent canalicular secretion calculated by extrapolating a single regression line to the $y$-axis was quite variable, both between animals and when repeated studies of canalicular flow were made in the same animal, even though the flow of bile per mole of bile acid output remained relatively constant. Because bile acids were infused randomly and at different rates, the possibility existed that bile acids were modifying the so-called bile acid-independent fraction of canalicular flow. Results of these studies indicate that taurocholate, a micelle-forming bile acid, may under the conditions of these studies increase biliary permeability and thereby stimulate its own choleretic response.

\section{METHODS}

Animals and drugs. In preparation for all studies, rhesus monkeys underwent total biliary diversion and were managed postoperatively as previously described (5). Briefly, cholecystectomy was performed through a midline incision under phencyclidine anesthesia (Bio-Ceutic Laboratories, St. Joseph, Mo.). A silastic catheter was then threaded into the proximal common bile duct, looped through a subcutaneous pouch, and passed into the distal common bile duct. The animals were allowed to recuperate for 1 mo after surgery before studies were performed. Hematocrits, bilirubin, and alkaline phosphatase were measured biweekly, and bromsulphalein transport maximum was determined frequently to monitor hepatic function as previously described (5). Tube patency was determined by cholangiography 2 wk after surgery and when liver chemistries or bromsulphalein transport maximum suggested obstruction, so that all animals were known to have patent bile ducts before study. All animals appeared well, gained weight throughout the period of study, and maintained stable hematocrits. In addition, specimens of bile cultured at the beginning of each study were sterile during the initial two studies of bile flow in every animal. Later cultures from some animals demonstrated Klebsiella, Escherichia coli, and Aerobacter species, yet the animals remained well.

Studies of bile flow were performed under phencyclidine anesthesia in the morning after the animals had fasted for $12 \mathrm{~h}$. An incision was made over the silastic tube, and the tube was opened for bile collection. Animals received normal saline, $50-100 \mathrm{ml}$ i.v., throughout each study and were infused with Sustagen (Mead Johnson \& Co., Evansville, Ind.) $3 \mathrm{ml} / \mathrm{h}$ by nasogastric tube to minimize spontaneous fluctuations in bile flow (4). Temperature was maintained at $38-38.5^{\circ} \mathrm{C}$ with a rectal thermometer and a heating pad. After the study the tube was rejoined with a tight-fitting silastic sleeve placed in the subcutaneous pouch, and the abdomen closed with a subcuticular suture. Animals were then returned to their cages where they were allowed to eat ad libitum and move freely.

Sodium taurocholate and sodium taurodehydrocholate (Calbiochem-Behring Corp., American Hoechst Corp. San Diego, Calif.) were examined by thin-layer chromatography and, when necessary, were recrystallized to obtain $>95 \%$ purity. All solutions were subjected to ultrafiltration to minimize infection. In an additional series of 14 experiments, sodium taurocholate $3.5,7.0$, or $10.5 \mu \mathrm{mol} / \mathrm{min}$ was infused intravenously in random order until bile flow was stable for three 15-min collection periods ( $\pm 15 \%$ variation), usually $1-2 \mathrm{~h}$. The same bile acid solution was continued for another $1.5 \mathrm{~h}$ and followed by the other two bile acid solutions for a similar period. $\left[{ }^{14} \mathrm{C}\right]$ erythritol (Amersham Corp., Arlington Heights, Ill.) 0.02 $\mu \mathrm{Ci} / \mathrm{min}$, was administered intravenously throughout the study for measurement of $\left[{ }^{14} \mathrm{C}\right]$ erythritol clearance. Bile was obtained at 15-min intervals throughout the study in tared glass containers kept on ice. Generally, heparinized blood specimens were drawn during the last three 15 -min collection periods for each bile acid infusion rate to determine $\left[{ }^{14} \mathrm{C}\right]-$ erythritol bile:plasma ratios.

In 16 other experiments performed in four different animals, taurocholic acid or taurodehydrocholic acid were infused at 7.0 and $3.5 \mu \mathrm{mol} / \mathrm{min}$ as described in the figure legends. Bile flow and $\left[{ }^{14} \mathrm{C}\right]$ erythritol clearance were again measured, and $\left[{ }^{3} \mathrm{H}\right]$ inulin (Amersham Corp.) was also infused at 0.08 $\mu \mathrm{Ci} / \mathrm{min}$ throughout the study for determination of $\left[{ }^{3} \mathrm{H}\right]$ inulin clearance.

Determinations. Samples of bile and plasma were transferred to $10 \mathrm{ml}$ Scintisol (Isolab, Inc., Akron, Ohio), and radioactivity was measured in all bile and plasma specimens by a Nuclear-Chicago scintillation counter (Nuclear-Chicago, Des Plaines, Ill.) with a double-labeled program when two isotopes were used. Correction for sample quenching was by the method of external standard ratios (17). Total bile acids were measured in each specimen by a modification of the 3-hydroxysteroid dehydrogenase method (18). All data were obtained with animals in steady state with respect to bile flow and $\left[{ }^{14} \mathrm{C}\right]-$ erythritol and $\left[{ }^{3} \mathrm{H}\right]$ inulin bile:plasma ratios. Bile flow, $\left[{ }^{14} \mathrm{C}\right]-$ erythritol clearance, and $\left[{ }^{3} \mathrm{H}\right]$ inulin clearance were plotted as a function of bile acid secretion rate, and correlation coefficients were determined by the least squares method with a standard computer program.

\section{RESULTS}

Bile flow and $\left[{ }^{14} \mathrm{C}\right]$ erythritol clearance during three rates of sodium taurocholate infusion. Bile flow and $\left[{ }^{14} \mathrm{C}\right]$ erythritol clearance were measured on four occasions in a single animal during random infusions of taurocholic acid (Fig. 1). With conventional linear regression analysis, $\left[{ }^{14} \mathrm{C}\right]$ erythritol clearance (canalicular bile flow) was significantly greater than bile flow, which suggests resorption of fluid as the primary bile secretion passes from the bile canaliculi to the collecting catheter (Fig. 1, Table I). Furthermore, although significant differences in slopes were not observed, the $y$ intercepts (the conventional measurement of bile acidindependent canalicular flow) calculated by extrapolating the single regression line to the ordinate varied considerably between studies (Fig. 1). 


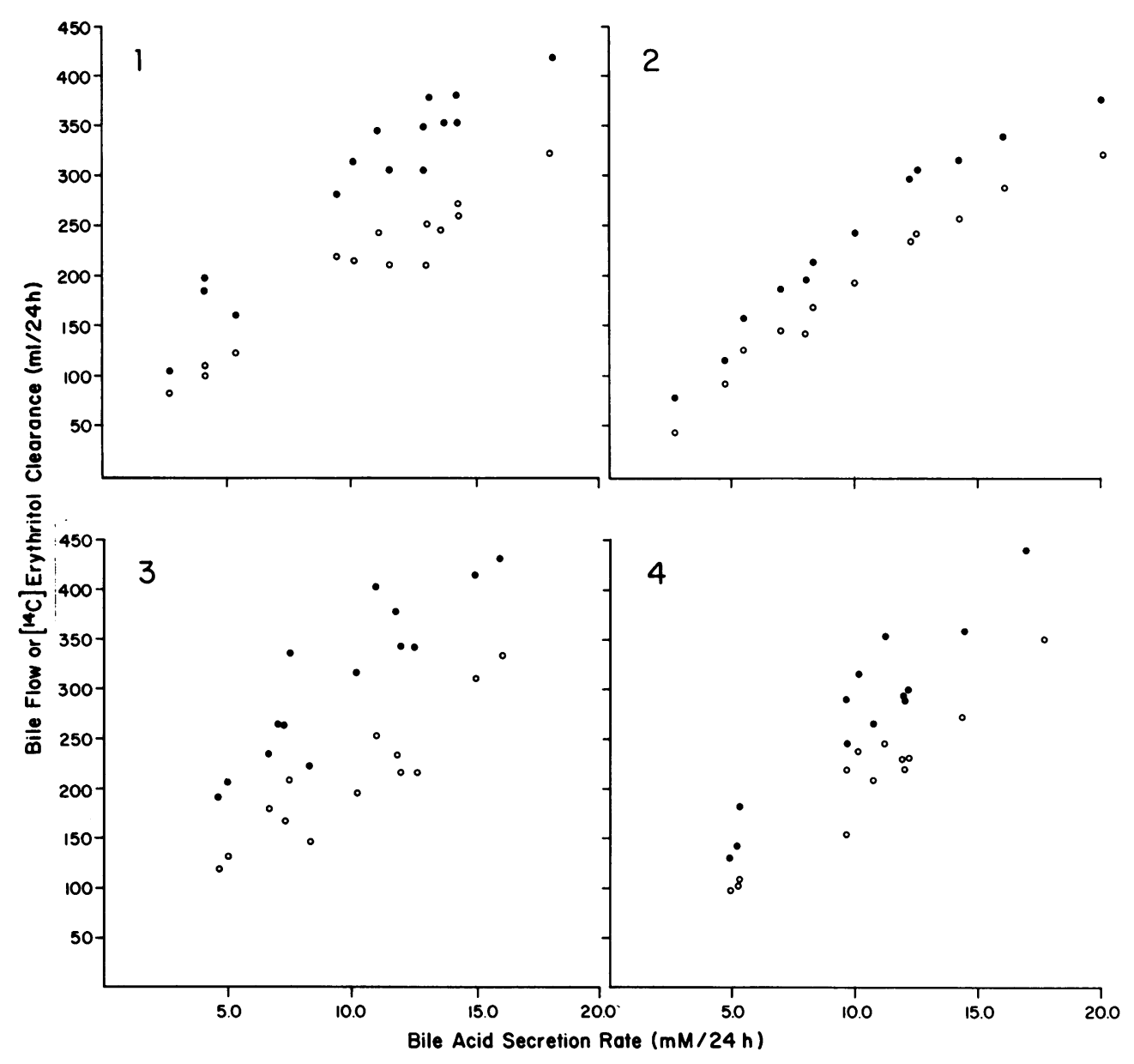

FIGURE $1 \quad\left[{ }^{14} \mathrm{C}\right]$ Erythritol clearance and bile flow as a function of bile acid secretion rate measured on four different occasions in a single female animal. $O=\left[{ }^{14} \mathrm{C}\right]$ erythritol clearance; $\bigcirc=$ bile flow. The slopes are not significantly different among the studies, but the $y$-intercepts determined with a conventional single regression line for canalicular bile flow vary widely; experiment 4 vs. 1 and $3, P<0.01$, and experiment 2 vs. $3, P<0.05$. Estimating equations for canalicular flow: experiment $1: y=107.2+18.3 x, r=0.94$; experiment $2: y=55.1+21.5 x, r=0.99$; experiment $4: y=6.0+23.1 x, r=0.87$; experiment $3: y=135.8+17.9 x, r=0.98$.

$\left[{ }^{14} \mathrm{C}\right]$ Erythritol clearance was measured during infusion of bile acids in 14 studies in five different animals using three rates of taurocholate infusion (Fig. 2). Although the correlation coefficient for the pooled data was $>0.90$, considerable variation was still observed between individual studies for values of $\left[{ }^{14} \mathrm{C}\right]$ erythritol clearance, whether data were expressed as milliliters per $24 \mathrm{~h}$ or as milliliters per kilogram body weight per $24 \mathrm{~h}$. Chronic cholangitis was one possible explanation for the variable canalicular flow which we observed, but bile was not infected during the first two studies of bile flow in any animal. Yet, canalicular flow, bile acid output, and bile output per micromole of secreted bile acid varied as widely in these experiments as in later studies where bile was infected. Sex differences in bile secretion might also have explained this variation; however, slopes and $y$-intercepts did not differ significantly between male and female animals (Table II).

For these initial measurements of $\left[{ }^{14} \mathrm{C}\right]$ erythritol clearance in rhesus monkeys, we used single regression lines to relate all values for $\left[{ }^{14} \mathrm{C}\right]$ erythritol clearance to bile acid secretion, although three rates of taurocholic acid were infused in random order. To determine whether this method of data analysis might account for the variation in the $y$-intercept individual regression lines relating $\left[{ }^{14} \mathrm{C}\right]$ erythritol clearance to bile acid secretion were calculated during each of the three rates of bile acid infusion in each study (Table III). The means of the $y$-intercepts measured during the highest and lowest rates of bile acid infusion were significantly different $(P<0.05)$, although individual values varied widely. 
TABLE I

Mean Bile Flow and Mean $\left[{ }^{14} \mathrm{C}\right]$ Erythritol Clearance Determined in Four Separate Studies in a Single Female Monkey

\begin{tabular}{|c|c|c|c|}
\hline Experiment & $\begin{array}{c}\text { Mean } \\
\text { bile acid } \\
\text { secretion }\end{array}$ & $\begin{array}{c}\text { Mean } \\
\text { bile flow }\end{array}$ & $\begin{array}{c}\text { Mean } \\
{\left[{ }^{14} \mathrm{C}\right] \text { erythritol }} \\
\text { clearance }\end{array}$ \\
\hline & $\mathrm{mmol} / 24 \mathrm{~h}$ & $m l / 24 h$ & $m l / 24 h$ \\
\hline 1 & 10.6 & 213.2 & 282.3 \\
\hline 2 & 11.0 & 153.8 & 235.5 \\
\hline 3 & 8.7 & 186.0 & 292.5 \\
\hline 4 & 9.4 & 189.5 & 240.6 \\
\hline Mean \pm SD & $9.9 \pm 1.1$ & $185.6 \pm 24.4$ & $262.7 \pm 28.9$ \\
\hline
\end{tabular}

$t=22.6, P<0.01$, paired $t$ test.

Effect of rate of taurocholate infusion on determinants of bile flow. To study whether differences in the order of taurocholate infusion could explain the varying $y$-intercepts observed with three bile acid infusion rates, bile flow and $\left[{ }^{14} \mathrm{C}\right]$ erythritol clearance were measured as a function of bile acid secretion with only two rates of bile acid infusion to simplify data analysis. Four animals were infused with taurocholate $7.0 \mu \mathrm{mol} / \mathrm{min}$ for $1.5 \mathrm{~h}$ followed by sodium taurocholate $3.5 \mu \mathrm{mol} / \mathrm{min}$ for $1.5 \mathrm{~h}$. The same experiment was repeated in four animals, except the bile acid solutions

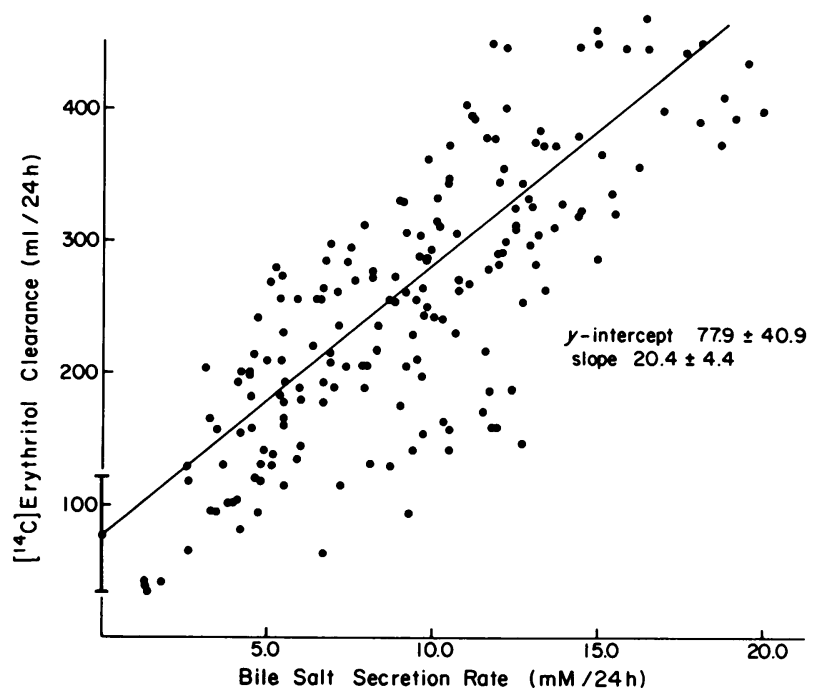

Figure $2 \quad\left[{ }^{14} \mathrm{C}\right]$ Erythritol clearance as a function of bile acid secretion rate determined in 14 separate studies with five different animals. Although $r=0.93, y$-intercepts for individual studies varied widely, as indicated by the wide standard deviation of the $y$-intercept determined with a conventional single regression line. All animals were of similar weight, so the variation between studies was similar, whether the $\left[{ }^{14} \mathrm{C}\right]-$ erythritol clearance was expressed as milliliters per $24 \mathrm{~h}$ or as milliliters per kilogram body weight per $24 \mathrm{~h}$.
TABLE II

$\left[{ }^{14} \mathrm{C}\right]$ Erythritol Clearance (Canalicular Bile Flow) in Male and Female Rhesus Monkeys

\begin{tabular}{ccrcc}
\hline Animal & Experiment & \multicolumn{1}{c}{$y$-Intercept } & \multicolumn{1}{c}{ Slope } & $\begin{array}{c}\text { Correlation } \\
\text { coefficient }\end{array}$ \\
\hline & & \multicolumn{1}{c}{$m l / 24 h$} & $m l / m m o l$ & $r$ \\
Males & & & & \\
1 & 1 & $47.1 \pm 25.9$ & $12.1 \pm 2.5$ & 0.80 \\
& 2 & $12.8 \pm 44.2$ & $18.9 \pm 4.2$ & 0.96 \\
& 3 & $50.1 \pm 15.7$ & $17.6 \pm 1.6$ & 0.95 \\
& 4 & $103.3 \pm 21.1$ & $16.8 \pm 1.8$ & 0.94 \\
& 5 & $72.6 \pm 30.9$ & $19.3 \pm 3.1$ & 0.90 \\
2 & 1 & $118.5 \pm 13.4$ & $21.1 \pm 1.4$ & 0.98 \\
& 2 & $121.6 \pm 72.3$ & $28.7 \pm 7.4$ & 0.87 \\
& 3 & $91.1 \pm 16.4$ & $25.4 \pm 2.2$ & 0.96 \\
Mean \pm SD & & $77.1 \pm 38.5$ & $20.1 \pm 5.3$ & \\
Females & & & & \\
1 & 1 & $107.2 \pm 23.7$ & $18.3 \pm 1.2$ & 0.94 \\
& 2 & $55.1 \pm 33.0$ & $21.5 \pm 2.9$ & 0.91 \\
& 3 & $135.8 \pm 34.3$ & $19.9 \pm 3.8$ & 0.86 \\
2 & 4 & $6.0 \pm 10.6$ & $23.1 \pm 1.0$ & 0.99 \\
3 & 1 & $49.0 \pm 17.7$ & $19.0 \pm 1.5$ & 0.96 \\
Mean \pm SD & 1 & $86.4 \pm 20.1$ & $\underline{18.4 \pm 2.3}$ & 0.94 \\
\cline { 2 - 3 } & & $73.8 \pm 46.0$ & $20.3 \pm 2.6$ & \\
\hline
\end{tabular}

Single regression lines were calculated by computer with at least 14 measurements of bile flow, $\left[{ }^{14} \mathrm{C}\right]$ erythritol clearance, and bile acid secretion in each experiment.

were administered in reverse order. When the data were analyzed with a conventional single regression line, the $y$-intercepts and the slopes for the $\left[{ }^{14} \mathrm{C}\right]$ erythritol clearance (canalicular flow) were augmented in the studies in which taurocholate $7.0 \mu \mathrm{mol} / \mathrm{min}$ was infused first (Fig. 3A).

Although the data appeared curvilinear by inspection, we were unable to fit a physiologically plausible curved function to the data with computer-assisted curve-fitting techniques. The results could be most accurately represented with two regression lines for each experiment, calculated with data points measured during each of the two bile acid infusion rates (Fig. 3B), as the slopes of the lines were significantly different during each bile acid infusion rate (Table IV). At lower rates of bile acid secretion, the $y$-intercepts appear to approach zero, which suggests that bile acid-independent flow becomes quite small. However, the slope of the regression line is greater at low bile acid infusion rates if the high bile acid infusion is given first, which indicates greater choleretic efficiency of the bile acid under these conditions (Fig. 3B).

When $\left[{ }^{3} \mathrm{H}\right]$ inulin bile:plasma ratios were measured in these same studies, constant values were obtained throughout each study but were significantly increased 
TABLE III

$\left[{ }^{14} \mathrm{C}\right]$ Erythritol Clearance as a Function of Bile Acid Secretion: $y$-Intercepts Calculated during each Bile Acid Infusion Rate

\begin{tabular}{|c|c|c|c|}
\hline & $\begin{array}{l}\text { During infusion } \\
\text { of } 3.5 \mu \mathrm{mol} / \mathrm{min}\end{array}$ & $\begin{array}{l}\text { During infusion } \\
\text { of } 7.0 \mu \mathrm{mol} / \mathrm{min}\end{array}$ & $\begin{array}{l}\text { During infusion } \\
\text { of } 10.5 \mu \mathrm{mol} / \mathrm{min}\end{array}$ \\
\hline & $m l / 24 h$ & $\mathrm{ml} / 24 \mathrm{~h}$ & $m l / 24 h$ \\
\hline & 38.4 & 57.6 & 174.8 \\
\hline & 55.1 & 58.4 & 78.6 \\
\hline & 95.8 & 148.6 & 158.7 \\
\hline & -8.6 & 40.6 & 28.1 \\
\hline & 66.8 & 48.4 & 102.6 \\
\hline & 21.5 & 96.8 & 126.6 \\
\hline & 72.9 & 81.4 & 135.2 \\
\hline & 4.6 & 82.0 & 114.0 \\
\hline & -5.3 & 8.5 & 68.7 \\
\hline & 74.4 & 93.6 & 104.5 \\
\hline & 62.5 & 78.6 & 38.1 \\
\hline & 33.4 & 192.6 & 147.8 \\
\hline & 7.9 & 50.6 & 83.9 \\
\hline & 170.1 & 190.5 & 168.3 \\
\hline Mean \pm SD & $49.3 \pm 43.3$ & $87.8 \pm 54.5$ & $109.3 \pm 44.6$ \\
\hline
\end{tabular}

$P<0.05,3.5 \mu \mathrm{mol} / \mathrm{min}$ vs. $10.5 \mu \mathrm{mol} / \mathrm{min}$; other comparisons not significant.

when the higher taurocholic acid infusion rate was given first (Fig. 4). This led to an increase in $\left[{ }^{3} \mathrm{H}\right]$ inulin clearance with increasing bile acid output (Fig. 5). These results suggested that changes in cell membrane or paracellular permeability might account for the augmented choleretic response observed when the higher rate of taurocholic acid infusion was given first.

Determinants of bile flow measured during sodium taurodehydrocholate administration. To determine whether a nonmicelle-forming bile acid, sodium taurodehydrocholate, also altered biliary permeability under the conditions of these experiments, bile flow and $\left[{ }^{14} \mathrm{C}\right]$ erythritol clearance were measured as a function of bile acid secretion rate in four animals infused with sodium taurodehydrocholate $3.5 \mu \mathrm{mol} / \mathrm{min}$ for $1.5 \mathrm{~h}$ followed by $7.0 \mu \mathrm{mol} / \mathrm{min}$ for $1.5 \mathrm{~h}$. In four other animals the same experiment was performed except that the infusion rates were reversed. In contrast to the finding with taurocholate infusions, there were no differences in $y$-intercept and slope when the higher rate of taurodehydrocholic acid was given first (Fig. 6). $\left[{ }^{3} \mathrm{H}\right]$ inulin clearance increased to a similar degree in these same studies with increasing rates of bile acid secretion (Fig. 7), and $\left[{ }^{3} \mathrm{H}\right]$ inulin bile:plasma ratios were similar in the two groups of experiments (Fig. 4). These results suggest that biliary permeability to $\left[{ }^{3} \mathrm{H}\right]$ inulin in these studies was not altered by the order of the taurodehydrocholic acid infusion (Fig. 4).

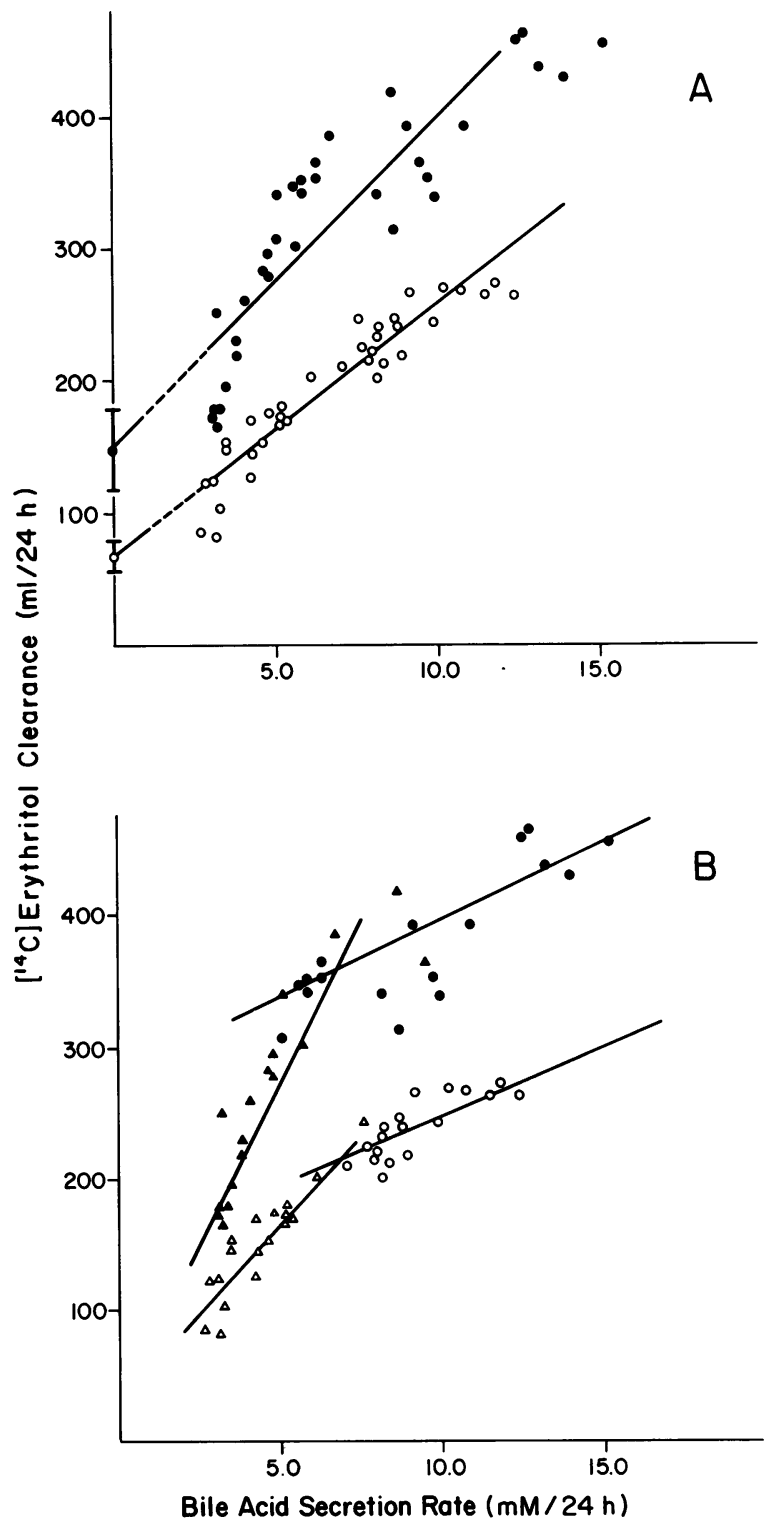

FIgURE 3 (A) $\left[{ }^{14} \mathrm{C}\right]$ Erythritol clearance as a function of bile acid secretion during infusion of taurocholic acid (O) 7.0 $\mu \mathrm{mol} / \mathrm{min}$ followed by $3.5 \mu \mathrm{mol} / \mathrm{min}$ or (O) $3.5 \mu \mathrm{mol} / \mathrm{min}$ followed by $7.0 \mu \mathrm{mol} / \mathrm{min}$, analyzed with conventional single regression lines. See text for experimental details. Estimating equations: $: y=149.6+24.1 x, r=0.87 ; \bigcirc: y=69.5+18.7 x$, $r=0.93$. The $y$-intercepts are significantly different, $\mathrm{P}<0.01$, and suggest alteration in bile acid-independent canalicular flow by order of bile acid infusion. (B) The data shown in Fig. 3A are divided into groups measured during infusion of taurocholic acid $7.0 \mu \mathrm{mol} / \mathrm{min}(O$ and $O$ ) or $3.5 \mu \mathrm{mol} / \mathrm{min}$ $(\Delta$ and $\Delta$ ) and replotted with individual regression lines. During lower rates of bile acid secretion, regression lines approach the origin, which suggests greater choleretic response from secreted bile acids at low rates of bile flow. Estimating equations: $\Delta: y=9.2+58.7 x, r=0.96 ; 0: y=284.9+14.8 x$, $r=0.98 ; \Delta: y=31.4+26.9 x, r=0.95 ; \bigcirc: y=141.0+11.3 x$, $r=0.94$. 
TABLE IV

$\left[{ }^{14} \mathrm{C}\right]$ Erythritol Clearance as a Function of Bile Acid Secretion: Slopes Calculated during each Bile Acid Infusion

\begin{tabular}{ccc}
\hline Experiment & $\begin{array}{c}\text { Slopes during } \\
\text { infusion of } \\
\text { taurocholic acid } \\
3.5 \mu \mathrm{mol} / \mathrm{min}\end{array}$ & $\begin{array}{c}\text { Slopes during } \\
\text { infusion of } \\
\text { taurocholic acid } \\
7.0 \mu \mathrm{mol} / \mathrm{min}\end{array}$ \\
\hline & $\mathrm{ml} / \mathrm{mmol}$ & $\mathrm{ml} / \mathrm{mmol}$
\end{tabular}

Taurocholic acid $3.5 \mu \mathrm{mol} / \mathrm{min}$ followed by $7.0 \mu \mathrm{mol} / \mathrm{min}$ *

\begin{tabular}{ccc}
1 & 26.7 & 11.8 \\
2 & 20.6 & 13.7 \\
3 & 36.5 & 9.3 \\
4 & 24.8 & 9.4 \\
\cline { 2 - 3 } Mean \pm SD & $27.2 \pm 6.7$ & $11.1 \pm 2.1$
\end{tabular}

Taurocholic acid $7.0 \mu \mathrm{mol} / \mathrm{min}$ followed by $3.5 \mu \mathrm{mol} / \mathrm{min} \ddagger$

\begin{tabular}{ccc}
1 & 48.6 & 14.6 \\
2 & 46.1 & 13.8 \\
3 & 58.1 & 15.1 \\
4 & 54.3 & 14.9 \\
\cline { 2 - 3 } Mean \pm SD & $51.8 \pm 5.5$ & $14.6 \pm 0.6$ \\
\hline
\end{tabular}

* $t=3.85, P<0.05$, paired $t$ test.

$\ddagger t=15.1, P<0.001$, paired $t$ test.

\section{DISCUSSION}

It has been customary to analyze the relationship between bile production and bile acid secretion by linear regression analysis, which relates the increment in bile flow to the rate of bile acid secretion. Such data have been collected from a variety of mammalian species including man, and indicate that bile acids are a major determinant of bile production, presumably through an osmotic effect, although the magnitude of flow generated per mole of secreted bile acid varies in different

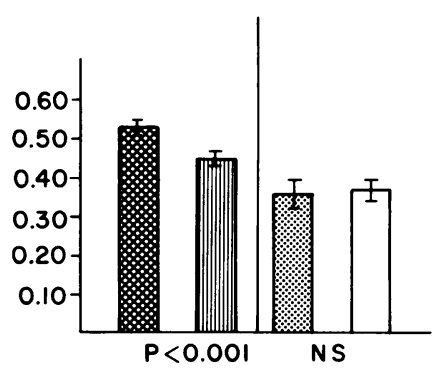

FIGURE $\left.4{ }^{3} \mathrm{H}\right]$ Inulin bile:plasma ratios during infusion of taurocholic acid $7.0 \mu \mathrm{mol} / \mathrm{min}$ followed by $3.5 \mu \mathrm{mol} / \mathrm{min}$ (hatched bar) and $3.5 \mu \mathrm{mol} / \mathrm{min}$ followed by $7.0 \mu \mathrm{mol} / \mathrm{min}$ (striped bar), and taurodehydrocholic acid $7.0 \mu \mathrm{mol} / \mathrm{min}$ followed by $3.5 \mu \mathrm{mol} / \mathrm{min}$ (shaded bar) and taurodehydrocholic acid $3.5 \mu \mathrm{mol} / \mathrm{min}$ followed by $7.0 \mu \mathrm{mol} / \mathrm{min}$ (open bar). The $\left[{ }^{3} \mathrm{H}\right]$ inulin bile:plasma ratios are significantly greater when $7.0 \mu \mathrm{mol} / \mathrm{min}$ taurocholic acid is infused first $(P<0.001)$. Bars represent means of studies in four animals, vertical lines equal \pm SEM.

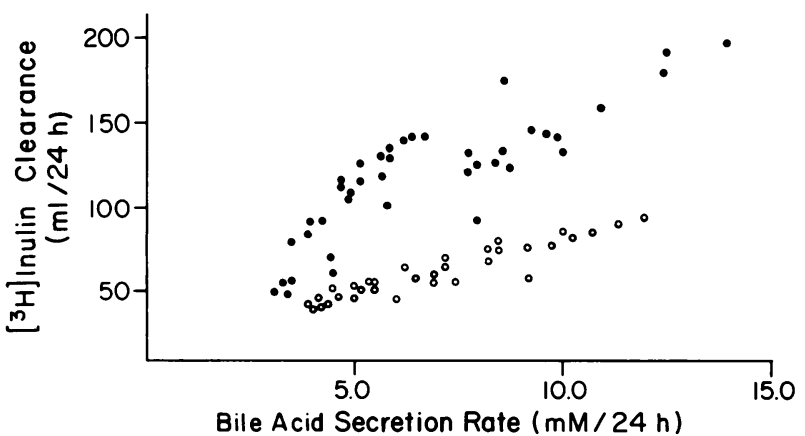

Figure $5 \quad\left[{ }^{3} \mathrm{H}\right]$ Inulin clearance as a function of bile acid secretion rate during infusion of taurocholic acid $7.0 \mu \mathrm{mol} / \mathrm{min}$ followed by $3.5 \mu \mathrm{mol} / \mathrm{min}(0)$ and $3.5 \mu \mathrm{mol} / \mathrm{min}$ followed by $7.0 \mu \mathrm{mol} / \mathrm{min}(\mathrm{O}) .\left[{ }^{3} \mathrm{H}\right]$ Inulin clearance is greater when the higher bile acid concentration is administered first. Estimating equations: 0 : $y=43.5+10.7 x, r=0.76$; $\bigcirc: y=16.6$ $+6.0 x, r=0.78$.

animals $(1-7,19,20)$. When canalicular bile secretion is determined by measurement of clearances of solutes such as erythritol or mannitol, extrapolation of the linear regression line to zero bile acid secretion has arbitrarily defined a bile acid-independent fraction, the origin of which is the subject of considerable investigation. This fraction of canalicular secretion has always been a derived value because it has never been possible to study bile secretion under conditions where bile acids were totally absent; some hepatic synthesis and excretion of bile acids always occurs even in the isolated perfused liver deprived of its enterohepatic circulation.

In these studies, when three rates of taurocholic acid were infused and data were analyzed using conventional single regression lines, the increase in bile production per mole of secreted bile acid was higher $(20.7 \mu \mathrm{l} / \mu \mathrm{mol}$ bile acid) than in $\operatorname{man}(7.0 \mu \mathrm{l} / \mu \mathrm{mol}), \operatorname{dog}$ $(8.0 \mu \mathrm{l} / \mu \mathrm{mol})$, or even the rat $(15.0 \mu \mathrm{l} / \mu \mathrm{mol})$ (Figs. 1 and 2). Although the reasons for these well-documented differences in the choleretic response to bile acids in different species are not entirely known, data from this study suggests that they might be related in part to permeability differences within the biliary tree, as will be discussed subsequently. In addition, basal bile production in these studies in rhesus monkeys was $15.0 \mu \mathrm{l} / \mathrm{min}$ per $\mathrm{kg}$ body wt, larger than the value of $\cong 6.0 \mu \mathrm{l} / \mathrm{min}$ per $\mathrm{kg}$ body wt in the dog and $\operatorname{man}(6,20)$, but considerably smaller than the average value of 65 $\mu \mathrm{l} / \mathrm{min}$ per $\mathrm{kg}$ body wt observed in rats (2).

The increment in $\left[{ }^{14} \mathrm{C}\right]$ erythritol clearance per mole of secreted bile acid was greater than that observed for total bile production (Fig. 1, Table I), unlike previous studies in the rhesus monkey where regression lines were parallel (4). However, in this study, bile:plasma ratios of $\left[{ }^{14} \mathrm{C}\right]$ erythritol were always constant and always $>1.0$ so that divergent regression lines would be 


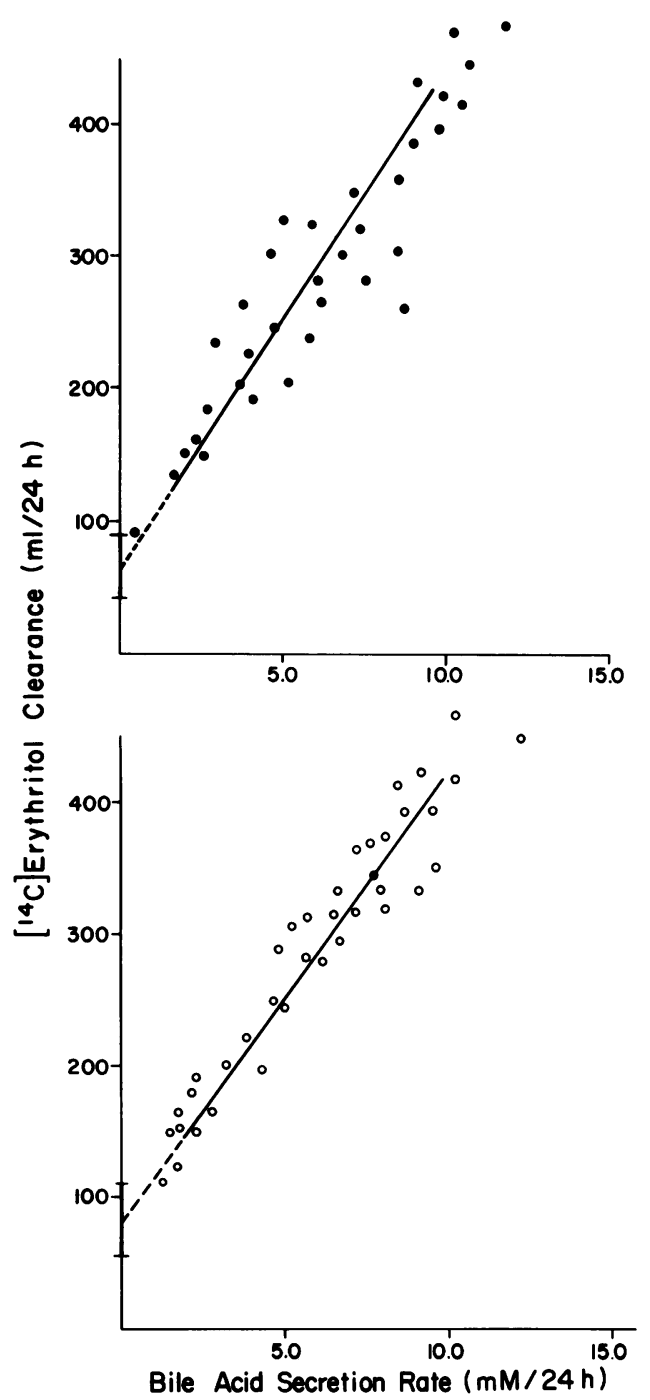

FigURE $6 \quad\left[{ }^{14} \mathrm{C}\right]$ Erythritol clearance as a function of bile acid secretion during infusion of taurodehydrocholic acid $7.0 \mu \mathrm{mol} /$ min followed by $3.5 \mu \mathrm{mol} / \mathrm{min}(\Theta)$ and $3.5 \mu \mathrm{mol} / \mathrm{min}$ followed by $7.0 \mu \mathrm{mol} / \mathrm{min}(O)$. Canalicular flow per mole of secreted bile acid is similar in the two studies. Estimating equations: O: $y=60.4+28.6 x ; \bigcirc: y=78.4+27.1 x$.

predicted. Similar findings have been reported in the dog, with $\left[{ }^{14} \mathrm{C}\right]$ erythritol and in the guinea pig with $\left[{ }^{14} \mathrm{C}\right]$ mannitol and have been interpreted as indicating ductular reabsorption of canalicular bile as the primary bile secretion passes along the biliary channels (1921). Such data are consistent with absorption by the bile ducts of a constant fraction of canalicular bile with increasing rates of canalicular secretion (22).

When the linear regression lines relating $\left[{ }^{14} \mathrm{C}\right]-$ erythritol clearance to bile acid secretion were extrapolated to the ordinate in this study, however, wide variation was found in the bile acid-independent fraction which was unanticipated (Figs. 1 and 2). However, when only two rates of taurocholic acid were infused, it became clear that the magnitude of the choleretic response could be substantially varied by the magnitude of the initial rate of bile acid infusion, and that a simple linear regression analysis of bile acid excretion and canalicular bile production does not accurately describe the relationship. Recent findings in bile acid-depleted rats have demonstrated that the relationship between bile flow and bile acid secretion is actually curvilinear, perhaps because micelle-forming bile acids such as taurocholate may increasingly aggregate and thus diminish their effective osmotic activity as the rate of bile acid excretion increases (23). The relationship between bile flow and bile acid secretion in monkeys may also be curvilinear; however, regression lines calculated from data points measured during infusion of each of the two bile acid infusion rates best described the data (Fig. 3). The lines calculated during the lower bile acid secretion rate approached zero bile flow and bile acid secretion more closely, regardless of the initial rate of bile acid infusion (Fig. 3B). These findings raise the distinct possibility that in the rhesus monkey micelle-forming bile acids such as taurocholate are the major determinant of hepatic bile formation and that the bile acid-independent fraction is either a misnomer or very small in size.

Although cholangitis and sex differences between animals do not explain these results, it is not entirely clear why reversing the order of bile acid infusion from high rates followed by low rates to low rates followed by high rates should modify the bile acid choleretic response. Perhaps this is related to the magnitude of

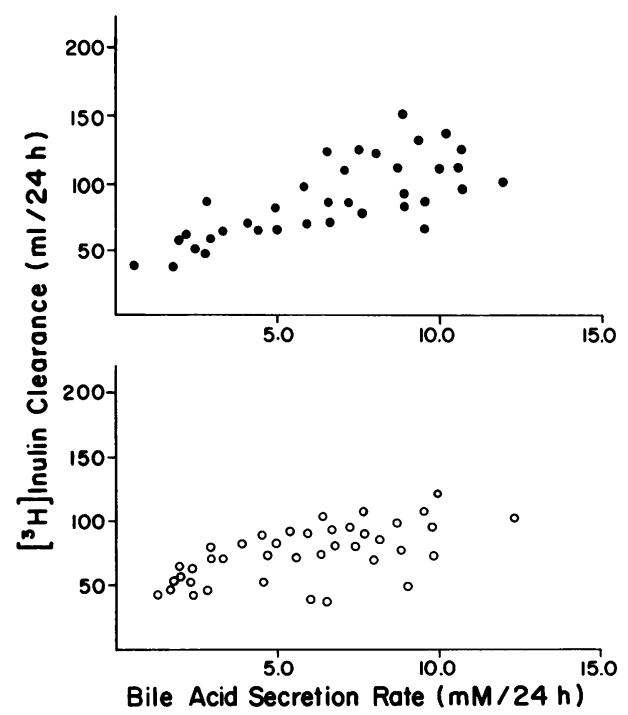

FIGURE $7 \quad\left[{ }^{3} \mathrm{H}\right]$ Inulin clearance as a function of bile acid secretion during infusion of taurodehydrocholic acid $7.0 \mu \mathrm{mol} / \mathrm{min}$ followed by $3.5 \mu \mathrm{mol} / \mathrm{min}(O)$ and $3.5 \mu \mathrm{mol} / \mathrm{min}$ followed by $7.0 \mu \mathrm{mol} / \mathrm{min}(\mathrm{O}) .\left[{ }^{3} \mathrm{H}\right]$ Inulin clearance per mole of secreted bile acid is similar in the two studies. Estimating equations: $0: y=31.6+13.6 x, r=0.82 ; \bigcirc: y=19.6+14.1 x, r=0.81$. 
the initial bile acid load which is presented to the liver for excretion and which interacts with portions of its cytoplasmic and surface membranes. Subsequent infusions of bile acids might then have less of a modifying effect, but the question remains to be explained. Nevertheless, the observation is clear and appears to be related specifically to the structure of bile acids as this phenomenon was seen only with the infusion of taurocholate, a micelle-forming bile acid which also stimulates hepatic phospholipid synthesis and excretion $(24,25)$, but was not observed with infusions of dehydrocholate, a bile acid which does not alter phospholipid metabolism (14).

These findings also suggest that taurocholate may influence the choleretic response by changing permeability at some point in the biliary tree. Evidence for this concept is derived from the effects of taurocholate infusion on $\left[{ }^{3} \mathrm{H}\right]$ inulin clearance and the absence of such effects when equimolar infusions of taurodehydrocholate were used. Thus, it is clear that the initial infusion of a high rate of taurocholate results in an increase in $\left[{ }^{3} \mathrm{H}\right]$ inulin bile:plasma ratios and $\left[{ }^{3} \mathrm{H}\right]$ inulin clearance for similar levels of bile acid secretion than when the lower rate of taurocholate was given first. By comparison, infusions of dehydrocholate did not change the choleretic response or alter inulin clearance when administered in a fashion similar to taurocholate. Differences in bile acid-dependent and -independent bile flow between species might therefore be related to differences in the type and quantity of bile acids which are excreted and their specific effects on membrane structure and function.

Because $\left[{ }^{3} \mathrm{H}\right]$ inulin bile:plasma ratios remained constant throughout each study at increasing rates of bile flow, solvent drag rather than diffusion was the major determinant of inulin entry into bile. The theoretical relationship between solvent flow and the entry of a solute like inulin into bile is illustrated in Fig. 8 and has been discussed in detail in previous publications (26-28). When we selected reflection factors to encompass the bile:plasma $\left[{ }^{3} \mathrm{H}\right]$ inulin ratios observed with the two orders of taurocholate infusion, and solved the equation for the diffusion permeability constant $(K)$, a doubling of $K$ is observed when the high rate of bile acid infusion is administered first (Fig. 8). These calculations lend further support to the concept that taurocholate is capable of altering biliary permeability.

The mechanism by which a change in permeability of the biliary tree occurs remains to be established, although several possibilities must be considered. Bile acids are amphipathic and are capable of insertion into the lipid-water interphase as has been suggested for erythrocytes (29-31), thus resulting in altered membrane permeability to water, inorganic anions, and inert molecules such as inulin. Scanning electron microscopic studies from our laboratory demonstrated irregularities and outpouchings in the canalicular surface membranes

$$
R=\frac{1-\sigma}{1-\sigma e^{-(1-\sigma) F / K}}
$$

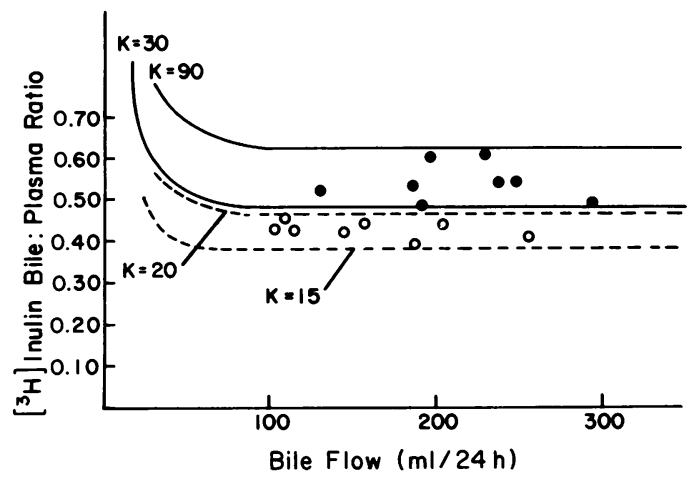

Figure 8 Predicted differences in the diffusion permeability constant $(\mathrm{K})$ during administration of $7.0 \mu \mathrm{mol} / \mathrm{min}$ taurocholic acid followed by $3.5 \mu \mathrm{mol} / \mathrm{min}$ (solid lines) and $3.5 \mu \mathrm{mol} / \mathrm{min}$ taurocholic acid followed by $7.0 \mu \mathrm{mol} / \mathrm{min}$ (broken lines). Reflection factors $(\sigma)$ were arbitrarily selected which enclosed the observed bile:plasma ratios, $1-\sigma$, and the predicted change in $\mathrm{K}$ was calculated from the equation. $\mathrm{F}=$ bile flow in milliliters per $24 \mathrm{~h}, \mathrm{R}=\left[{ }^{3} \mathrm{H}\right]$ inulin canalicular bile:plasma ratio.

of rats infused with bile acids, alterations which might occur through such a bile acid-canalicular membrane interaction and account for some of the differences in choleretic effect which we observed. In addition, an initial infusion of $7.0 \mu \mathrm{mol} / \mathrm{min}$ taurocholic acid might produce an increase in hepatic synthesis of phosphatydyl choline $(24,25)$, thus resulting in an increase in the phospholipid:cholesterol ratio in canalicular membranes and enhanced membrane permeability, an effect not observed with dehydrocholic acid (14).

Alteration in the permeability of the hepatocyte junctional complexes is yet another mechanism whereby taurocholate may increase the biliary clearance of inulin and augment its choleretic effect, particularly because recent studies in the rat indicate that taurocholate and taurodehydrocholate-induced choleresis increase hepatocyte junctional permeability to ionic lanthanum (16). If such a mechanism occurs in the rhesus monkey, it remains unclear why the increase in $\left[{ }^{3} \mathrm{H}\right]$ inulin clearance was observed only with taurocholate and not with taurodehydrocholate, although species differences of bile acid effects on junctional anatomy might explain this difference.

A final possibility is that bile acids such as taurocholate may modify the activity of liver plasma membrane $\mathrm{Na}^{+}$, $\mathrm{K}^{+}$-ATPase which in turn may be linked to the generation of bile acid-independent secretion. Although recent studies, which localize this enzyme to basolateral portions of the hepatocyte, cast doubt on the concept of a simple sodium-potassium exchange across the apical or canalicular membrane (32), $\mathrm{Na}^{+}, \mathrm{K}^{+}$-ATPase activity does correlate with bile acid-independent secretion in many studies (1, 3, 8-13). Wannagat et al. 
(15) have demonstrated enhanced bile acid-independent canalicular flow and high specific activity of $\mathrm{Na}^{+}, \mathrm{K}^{+}$. ATPase in canalicular membranes from livers of animals subjected to partial bile duct ligation or given $48-\mathrm{h}$ infusions of bile acids. These findings imply that there is a relationship between bile acid flux and the activity of these membrane enzymes. Unfortunately, the permeability of the biliary tree has not been measured in this model.

Whatever the final explanation, these findings emphasize the close relationship between bile acid flux, biliary permeability, and the magnitude of the choleretic response associated with bile acids. The possibility must be considered that the flux of bile acids into bile may have a major influence on bile acid-independent canalicular flow.

\section{ACKNOWLEDGMENTS}

This study was supported in part by a grant from the Frankel Fund, Chicago, Ill., and by U. S. Public Health Service grant AM-17153.

\section{REFERENCES}

1. Berthelot, P., S. Erlinger, D. Dhumeaux, and A. M. Preaux. 1970. Mechanism of phenobarbital-induced hypercholeresis in the rat. Am. J. Physiol. 219: 809-813.

2. Boyer, J. L. 1971. Canalicular bile formation in the isolated perfused rat liver. Am. J. Physiol. 221: 1156-1163.

3. Erlinger, S., D. Dhumeaux, P. Berthelot, and M. Dumont. 1970. Effect of inhibitors of sodium transport on bile formation in the rabbit. Am. J. Physiol. 219: 416-422.

4. Strasberg, S. M., R. G. Ilson, K. A. Siminovitch, D. Brenner, and J. E. Palaheimo. 1975. Analysis of the components of bile flow in the rhesus monkey. Am. J. Physiol. 228: 115-121.

5. Wood, R. A. B., A. L. Baker, A. W. Hall, J. L. Boyer, and A. R. Moossa. 1976. Evaluation of a new monkey model for the repeated study of bile secretory physiology. Ann. Surg. 185: 349-355.

6. Boyer, J. L., and J. R. Bloomer. 1974. Canalicular bile secretion in man. Studies utilizing the biliary clearance of $\left[{ }^{14} \mathrm{C}\right]$ mannitol. J. Clin. Invest. 54: 773-781.

7. Prandi, D., S. Erlinger, J. C. Glasinovic, and M. Dumont. 1975. Canalicular bile production in man. Eur. J. Clin. Invest. 5: 1-6.

8. Boyer, J. L., and D. Reno. 1975. Properties of $\left(\mathrm{Na}^{+}+\mathrm{K}^{+}\right)$activated ATPase in rat liver plasma membranes enriched in bile canaliculi. Biochim. Biophys. Acta. 401: 59-72.

9. Erlinger, S. 1972. Physiology of bile flow. In Progress in Liver Disease. H. Popper and F. Schaffner, editors. Grune \& Stratton, Inc., New York. IV: 63-82.

10. Gumucio, J. J., L. Accatino, A. M. Macho, and A. Contreras. 1973. Effect of phenobarbital on the ethynyl estradiolinduced cholestasis in the rat. Gastroenterology. 65: 651-657.

11. Simon, F. R., E. Sutherland, and L. Accatino. 1976. The effect of cholestasis produced by ethinyl estradiol (EE) on bile acid binding and (Na-K)ATPase activity in rat liver surface membranes. Clin. Res. 24: 105A. (Abstr.)

12. Layden, T. J., and J. L. Boyer. 1976. The effect of thyroid hormone on bile salt-independent bile flow and $\mathrm{Na}^{+}, \mathrm{K}^{+}$ATPase activity in liver plasma membranes enriched in bile canaliculi. J. Clin. Invest. 57: 1009-1018.

13. Simon, F. R., E. Sutherland, and L. Accatino. 1977. Stimu- lation of hepatic sodium and potassium-activated adenosine triphosphatase activity by phenobarbital. Its possible role in regulation of bile flow. J. Clin. Invest. 59: 849-861.

14. Nemchansky, B. A., T. J. Layden, and J. L. Boyer. 1977. Effects of chronic choleretic infusions of bile acids on the membrane of the bile canaliculus. Lab. Invest. 36: 259-267.

15. Wannagat, F-J., R. D. Adler, and R. K. Ockner. 1978. Bile acid-induced increase in bile acid-independent flow and plasma membrane NaK-ATPase activity in rat liver. $J$. Clin. Invest. 61: 297-307.

16. Layden, T. J., E. Elias, and J. L. Boyer, 1978. Bile formation in the rat. The role of the paracellular shunt pathway. J. Clin. Invest. 62: 1375-1385.

17. Bush, E. T. 1963. Application of the channels ratio method of measuring liquid scintillation efficiency. Anal. Chem. 35: 1024. (Abstr.)

18. Javitt, N. B., and S. Emerman. 1968. Effect of sodium taurolithocholate on bile flow and bile acid excretion. J. Clin. Invest. 47: 1002-1014.

19. Forker, E. L. 1967. Two sites of bile formation as determined by mannitol and erythritol clearance in the guinea pig. J. Clin. Invest. 46: 1189-1195.

20. Wheeler, H. O., E. D. Ross, and S. E. Bradley. 1968. Canalicular bile production in dogs. J. Clin. Invest. 214: 866-874.

21. O'Maille, E. R. L., and T. G. Richards. 1976. The secretory characteristics of dehydrocholate in the dog in comparison with the natural bile salts. J. Physiol. (Lond.). 261: 337-357.

22. Forker, E. L. 1977. Mechanisms of hepatic bile formation. Annu. Rev. Physiol. 39: 323-349.

23. Balabaud, C., K. A. Kron, and J. J. Gumucio. 1977. The assessment of the bile salt-nondependent fraction of canalicular bile water in the rat. J. Lab. Clin. Med. 89: 393-399.

24. Balint, J. A., D. A. Beeler, E. C. Kyriakides, and D. H. Treble. 1971. The effect of bile salts upon lecithin synthesis. J. Lab. Clin. Med. 77: 122-133.

25. Gregory, D. H., Z. R. Vlahcevic, P. Schatzki, and L. Swell. 1975. Mechanism of secretion of biliary lipids. I. Role of bile canalicular and microsomal membranes in the synthesis and transport of biliary lecithin and cholesterol. J. Clin. Invest. 55: 105-114.

26. Forker, E. L. 1968. Bile formation in guinea pigs. Analysis with inert solutes of graded molecular radius. Am. J. Physiol. 215: 56-62.

27. Forker, E. L. 1969. The effect of estrogen on bile formation in the rat. J. Clin. Invest. 48: 654-663.

28. Layden, T. J., and J. L. Boyer. 1977. Taurolithocholate induced cholestasis: taurolithocholate but not dehydrocholate reverses cholestasis and bile canalicular membrane injury. Gastroenterology. 73: 120-128.

29. Deuticka, B. 1968. Transformation and restoration of biconcave shape of human erythrocytes induced by amphipathic agents and changes of ionic environment. Biochim. Biophys. Acta. 163: 494-500.

30. Cooper, R. A., F. A. Garcia, and C. Trey. 1972. The effect of lithocholic acid on red cell membranes in vivo. J. Lab. Clin. Med. 79: 7-18.

31. Cooper, R. A., M. Diloy-Puray, P. Lando, and M. S. Greenberg. 1972. An analysis of lipoproteins, bile acids, and red cell membranes associated with target cells and spur cells in patients with liver disease. J. Clin. Invest. 51: 3182-3192.

32. Blitzer, B. L., and J. L. Boyer. 1978. Cytochemical localization of $\mathrm{Na}^{+}, \mathrm{K}^{+}$-ATPase in the rat hepatocyte. J. Clin. Invest. 62: 1104-1108. 